\title{
Globalization and \\ financial crises in Latin America
}

\section{Roberto Frenkel}

Senior Researcher,

Centro de Estudios de Estado

y Sociedad (CEDES),

Professor at the University

of Buenos Aires,

Director of the Banco de la

Provincia de Buenos Aires

frenkelr@bapro.com.ar

\author{
This article focuses on the financial and currency crises that \\ have occurred in the context of financial globalization in \\ Latin America. It is divided into four sections. The first \\ provides an overview of financial globalization in the last \\ three decades. The second offers a model applicable both to \\ the 1990s crises and those of the early 1980s. The third \\ examines other experiences of globalization that did not lead \\ to crises and analyses preventive measures in the light of \\ these. The fourth reviews the routes that lead to segmented \\ financial integration and touches on the problems of \\ international coordination.
}


I

\section{Three decades of financial globalization} in Latin America

The modern-day financial globalization process dates back three decades. Its beginnings can be traced to between 1971 and 1973, the period when the United States broke the link between the dollar and gold and the currencies of the main developed countries were floated. The abandonment of the fixed exchange-rate regime that had applied since the Bretton Woods agreements transferred currency risk to the private sector and stimulated the development of the currency and currency derivatives markets (Eatwell, 1997).

Another early milestone was the oil price rise decided on by the Organization of Petroleum Exporting Countries (OPEC) in 1973. The first oil shock resulted in large trade imbalances, which had to be financed. The eurodollar market experienced a sharp rise in demand, while the surpluses of the oil exporting countries supplied it with ample liquidity.

Financial globalization is a historical process with two dimensions. One is the growing volume of crossborder financial transactions; the other is the sequence of institutional and legal reforms implemented to liberalize and deregulate international capital movements and national financial systems.

Quantitative growth and institutional and legal changes have been mutually reinforcing. Competition in capital markets has provided a major stimulus. As deregulated international intermediaries began to provide lower-cost services, this created pressure for cost reductions and fewer regulations at the national level. The new opportunities opening up in certain countries drove deregulation of transactions between countries (D’Arista, 2002).

Financial integration has always been mainly a developed-country affair. It is notable, however, that the largest economies in Latin America were part of the globalization process from the start. First Brazil,

$\square$ An earlier version of this article was used as the basis for discussion by Working Group II at the Second Plenary Meeting of the Interparliamentary Forum of the Americas (Panama City, 20 and 21 February 2003). The author is grateful for the assistance of Martín Rapetti and the remarks and suggestions of an anonymous CEPAL Review referee. and then Mexico, Venezuela, Argentina and Chile were large recipients of capital in the 1970s. These last two countries, along with Uruguay, then pioneered drastic liberalizing reforms which anticipated those that were to be applied so widely in the 1990s.

The participation of Latin America in financial globalization was interrupted by the debt crisis of the 1980s. This caused a hiatus of about eight years, during which voluntary financing dried up. Then in the $1990 \mathrm{~s}$ the region re-entered the process vigorously, carrying out drastic reforms and becoming a recipient of growing flows (and ebbs) of capital. Just as the Mexican moratorium of 1982 is said to have marked the beginning of the debt crisis period, Mexico's signing of the first agreement under the Brady Plan may be cited as a landmark in the commencement of the most recent phase. ${ }^{1}$

\section{International financing in the "lost decade"}

The first period of strong capital inflows into developing economies was cut short by profound internal and external financial crises in 1981 and 1982. These crises were followed by nationalization (through mechanisms that differed from country to country) of many external private-sector debts and by the establishment of an institutional system whereby each country's external financing had to be settled by negotiation with lending banks and the International Monetary Fund (IMF). During this period, the regime under which the region operated was characterized by two stylized facts: i) external financing was rationed and ii) negotiations with creditors and international financial organizations generally resulted in net transfers abroad on a scale that was substantial in macroeconomic terms. Consequently, it would be wrong to say that the region became "detached" from globalization in the 1980s. What happened was that the region was practically

\footnotetext{
${ }^{1}$ The renewed involvement of Latin America and the inclusion of Asian and formerly Socialist countries as new emerging markets led to a large increase in the scale of operations in the global financial system.
} 
debarred from obtaining new voluntary financing, but continued to be strongly tied to the international system by the negotiated service of debts contracted during the earlier period.

Later, as a result of their early participation in financial globalization and the economic disaster this led to, a number of the region's economies, particularly the larger ones, went into the new financial boom of the 1990s with a large legacy of external debt.

\section{Events and ideas in the 1990s}

After re-entering the international system in the early 1990s, the region experienced an upsurge in capital flows that came to an abrupt end with the Mexican crisis. The downturn was short and was followed by a new influx, in which foreign direct investment (FDI) was now more prominent. This cyclical pattern seems to have come to an end with the Asian crisis, as will be seen further on.

In the first of these booms, the predominant idea was that this was the beginning of a long period of growth in emerging-market capital inflows, part of an international movement towards deeper financial links. This was the basic diagnostic in multilateral organizations and the region's governments, and it was a view generally shared by international intermediaries and investors. It was thought that this process would tend uninterruptedly towards the full integration of emerging markets into a global market. The prospect of a crisis was simply dismissed, and even less consideration was given to the possibility of herd movements like those that were subsequently to occur.

The scope and scale of the first upsurge in the 1990s were due in part to investors thus underestimating the risks, and this helped turn the strength of capital flows into a self-fulfilling prophecy. The Mexican crisis and its aftermath laid bare the risks and revealed the extent of volatility. They also, however, revealed the potential effectiveness of international intervention, as the unprecedented international assistance provided at that time paved the way for a rapid recovery in financial market confidence and allowed Mexico and other countries affected by contagion (chiefly Argentina) to meet all their financial obligations. This set the stage for a new boom, which lasted until the Asian crisis.

\section{After the Asian, Russian and Brazilian crises}

Following recovery from the Asian, Russian and Brazilian crises, the idea took hold that the international financial integration process was cyclical in nature (Calvo, Leiderman and Reinhart, 1996; IMF, 1997), so that a new upturn was to be expected. This was the belief, for example, of the economic authorities who took office in Argentina in late 1999. This optimistic outlook was encouraged by the relatively benign character of the crisis in Brazil and the effectiveness of the action taken by international agencies to forestall a payment moratorium in most cases.

Other events, however, showed that the process had taken a new direction. Firstly, net capital inflows did not increase from the lows seen in 1998. Secondly, the risk premiums of certain countries that were large enough to have a significant effect on the average emerging economy risk rating (and also the risk premiums of some countries with smaller amounts of debt) remained systematically high, never being less than double the risk premium values of the boom periods. The countries' asset price dynamic also showed some novel features. Movements in risk premiums and private-sector capital flows were driven by new forms of contagion, in addition to that resulting from individual country crises. The effects of the oil price rise in 2000 and the NASDAQ collapse in 2001 are examples of this.

The decline in flows from 1998 onward and the change in their dynamic were associated with other important shifts in the international context of the 1990s. These changes coincided with the ending of a long period of expansion in the United States economy, and thus with the demise of expectations that growth would be continuous, without recessionary interludes. These expectations had been rationalized by reference to the novel circumstances supposedly created by the "new economy" in the macroeconomic dynamic of the United States.

Another event at this time was the bursting of the technology share bubble in the United States and the major negative wealth effect this had. The bubble developed in parallel with the emerging market boom, and it was these two types of assets that represented between them the new high-yielding investment opportunities at that time. The negative effects on demand for emerging market assets caused by the revision of earnings expectations and the losses resulting from the collapse of "new economy" shares were compounded by increased uncertainty.

As regards the supply of assets, the role played by emerging markets in the region was likewise less prominent at the end of the 1990s than it had been at the beginning. The countries' external sector, and thus their ability to meet their external obligations, changed 
over the course of the decade, largely because of globalization itself. The way they participated in the international economy shifted over these years. The counterpart of net capital inflows was an expansion in the share of foreign capital and rising international debt in the public and private sectors. This has been reflected in the balance-of-payments current account by steady growth in external factor rents. In some significant cases, growth in capital rents has not been offset by net export growth, and structural current-account deficits have been the result. Many of the problems faced by these countries result from this imbalance between international finance and trade.

\section{II External crises}

\section{Crises in the recent phase}

A number of Latin American countries have experienced domestic and external financial crisis during the phase that began in the 1990s, with dramatic effects on the real economy. Crises generally entail high economic and social costs and recession. Regional contagion is another striking effect. A crisis in one country has repercussions for financing costs and capital flows in others. This phenomenon first came clearly to light with the Mexican crisis of 1994-1995. The "Tequila effect" swept the region and other emerging markets and helped trigger the 1995 Argentine crisis. Contagion effects were more pronounced in 1997 and afterwards. The effects of the 1997-1998 Asian crisis and the 1998 Russian crisis were universal, and not only Brazil and Argentina, but other Latin American countries that were more strongly placed, felt the impact of contagion (Ffrench-Davis, 2001).

The crises in Mexico (1994-1995), Argentina (1995), Brazil (1998-1999) and Argentina again (20012002) broke out in the very countries that had received the largest capital inflows during the preceding booms. They are also the largest economies in Latin America and the largest "emerging markets" in the region.

A brief review of these cases will be enough to identify certain common features in the institutional and economic policy situation at the time these crises occurred: i) the nominal exchange rate was fixed or semi-fixed; ii) the real exchange rate was high; iii) there
In the late 1990s, highly indebted countries found that they needed resources to roll over their debts and cover their current-account deficits, largely generated by capital service payments (interest and profits). The balance-of-trade deficit became less important than the growing deficit in the financial and factor services accounts. Although the situation was not the same across the region, in 2001 it involved countries such as Argentina and Brazil that accounted for a large proportion of emerging-market and Latin American debt. In late 2002, Argentina was in default and the Brazilian market was closed to new issues. $^{2}$

were virtually no barriers to the free movement of capital; iv) capital inflows in the preceding boom had been large in relation to the size of existing local money and capital markets; v) the regulation of national financial systems during the boom phase was weak and permissive. $^{3}$

Besides the characteristics mentioned, more detailed analyses of these experiences reveal a cyclical macroeconomic dynamic in all cases, with an initial expansionary phase followed by a period of stagnation or recession and growing financial weakness domestically and externally, culminating in financial and currency crises. The Argentine economy went through this cycle twice in the decade, because the convertibility regime outlasted the 1995 Tequila crisis. After that year the Argentine economy went through another brief expansion, supported by a fresh rise in capital inflows that lasted until the Asian crisis. The turning point of this second cycle came in 1998.

\footnotetext{
2 The Brazilian bond market reopened in April 2003 and the Government issued US\$ 1 billion of new debt at $10.7 \%$.

${ }^{3}$ System regulation was reformed and strengthened in Argentina after the 1995 crisis, so that it had become more robust by the time of the 1996-1997 upsurge in capital inflows. In Argentina, however, there was systemic currency risk owing to the partial dollarization of the domestic financial system. While banks had matched their local dollar assets and liabilities and did not seem to face any currency risk individually, much of their dollar lending was to agents with peso income from non-tradable activities.
} 
The institutional and macroeconomic policy conditions whose characteristics are listed above resulted from the implementation of programmes that combined reforms such as trade and capital-account liberalization (plus privatization, fiscal reforms and moves towards deregulation in other markets) with antiinflationary macroeconomic policies in which fixed or semi-fixed exchange rates played a crucial role. Mexico implemented a programme of this sort in 1988, Argentina in 1991 and Brazil in 1994.

\section{Experiments in the Southern Cone}

It was mentioned above that some of the region's early efforts to engage with the international financial system (Argentina and Chile in the 1970s) anticipated the models that would be so widely followed in the 1990s. The "Southern Cone liberalization experiments" combined drastic financial and trade reforms with macroeconomic arrangements involving pre-set exchange rates and passive monetary policy. The reforms included liberalization and deregulation of capital flows, liberalization of local financial markets and moves towards free trade. Fixed exchange rates were meant to bear down on inflation. These policy experiments resulted in moves towards financial and trade liberalization and deregulation in situations of plentiful external funding and with high fixed exchange rates (Fanelli and Frenkel, 1993; Frenkel, 2002).

These 1970s experiments display the same combination of local conditions and surging capital inflows as were seen in the critical cases of the 1990s. Furthermore, the processes to which the Southern Cone experiments gave rise were similar to those that subsequently led to the crises in Mexico, Brazil and Argentina during the recent phase. Although the 1970s experiences were shorter-lived than the recent cases, the macroeconomic dynamic displayed the same cycle of boom, bust and crisis.

Chile and, a little later, Argentina initiated their new currency programmes in 1978. By late 1979, when United States monetary policy raised interest rates, Argentina and Chile already had large external debts and substantial current-account deficits. From then on, higher international interest rates further contributed to external fragility. The crises broke out shortly afterwards. The exchange-rate regime collapsed early in 1981 in Argentina and in 1982 in Chile. External financial markets closed to both these economies in the latter year, and in both cases massive bail-outs of the local financial system were organized at great fiscal expense. Both countries went into deep recessions.

The rise in the international interest rate in late 1979 accelerated the process. What the two countries experienced, however, had the hallmarks of an endogenous cycle, with a turning point and subsequent recessionary phase emerging independently of international interest-rate movements. As in the more recent cases, this cycle involved the domestic financial system, movements in the external account and reserves, and a rise in borrowing.

There are a number of reasons for discussing the experience of the Southern Cone. Neither budget deficits nor government guarantees for bank deposits -potential sources of moral hazard-played significant roles in the crises. Both were present in Argentina, but Chile had a budget surplus and the bank deposit guarantee had been abolished with the explicit aim of making the financial system more efficient and less risky.

IMF strongly supported these policy experiments. In 1980 and 1981, when Chile was running large current-account deficits, IMF argued that this situation should not be a concern so long as it was not accompanied by a fiscal deficit, which at that time it was not in Chile. ${ }^{4}$ IMF subsequently took the same view of the situation in Mexico in 1994. ${ }^{5}$ On both occasions, the basis of the diagnostic was that rational behaviour by the private sector would ensure that resources borrowed from abroad were allocated efficiently and would be repaid.

The crisis to which the Southern Cone experiments led had a major intellectual impact. The Chilean case was particularly striking because it contained all the ingredients that ought to have guaranteed success and stability, according to the fashionable theory that underlay the country's policies. The experiments were based on a version of the modern "monetary approach to the balance of payments", the vision forged at the University of Chicago in the heat of the recent restoration of a world capital market.

Studies and debates dealing with the experience of the Southern Cone gave rise to a body of economic literature, the so-called "sequencing literature" (Fanelli and Frenkel, 1993). The main conclusion of this literature was that the crises had resulted from faulty

\footnotetext{
${ }^{4}$ See, for example, Robichek (1981), cited in Díaz Alejandro (1985).

${ }^{5}$ Michel Camdessus took a similar position on Mexico when he visited that country in 1994.
} 
sequencing of the reforms. Basically, it was argued that they were caused by premature financial liberalization. The resulting policy recommendation was that capital markets should be opened only once the economy had been stabilized and was open to international trade, with a robust financial system, i.e., only once a sequence of policies had been applied (the policies that would later form the core of the Washington Consensus) and the effects expected from the first reforms had fully manifested themselves.

What these observations show is that in the first half of the 1990s, when there was a new upsurge in capital inflows, there was no lack of historical experience, analytical studies or policy recommendations to provide a basis for examining the processes then going on in Mexico and Argentina. The Southern Cone experiments had taken place barely a decade before and had been repeatedly analysed. Yet the memory of these cases and the lessons drawn from them were not mentioned by IMF, or in the work of market analysts, or in much of the academic output. Even more striking is the way the experience of the Southern Cone and the sequencing literature were forgotten by some of those who had participated actively in that debate and contributed to the literature, and who then came to hold important positions in the new phase, such as Anne Krueger, the current Managing Director of IMF (Krueger, 1986) and Sebastián Edwards, former Chief Economist for Latin America at the World Bank (Edwards, 1986). ${ }^{6}$ Such was the degree of memory loss about the crises that the conventional interpretation which became established after the Mexico crisis treated this as though it were a bolt from the blue.

\section{The cyclical dynamic leading to crisis $^{7}$}

The starting point for the cycle that characterized the cases of the 1970s and 1990s was a combination of

\footnotetext{
${ }^{6}$ We have drawn attention to the way the issue of reform sequencing was "overlooked" in writings reflecting mainstream economic opinion. Perhaps less striking (because it is more common) is the total ignorance displayed of studies published in the Southern Cone countries and by less conventional analysts, such as Frenkel (1980, 1983a and 1983b) and Damill and Frenkel (1987) in Argentina, and Arellano (1983), Ffrench-Davis and Arellano (1983) and Díaz Alejandro (1985) in Chile.

${ }^{7}$ This account is based on a model inspired by the experiences of Argentina and Chile which is presented in Frenkel (1983a). The model was synthesized and presented in English in Williamson (1983) and Taylor (1991). It was also used in explaining the 1990s crises by Taylor (1998), Eatwell and Taylor (2000) and Frenkel (2002).
}

local programmes with an upsurge in capital flows to emerging markets. It is in fact the abundance of cheap international financing that provides the preconditions for the viability of such policy packages.

The launch of these programmes is followed by massive capital inflows, an initial build-up of reserves and high rates of money and credit growth. Internal demand expands strongly and a bubble is inflated in real and financial assets such as land, real estate and shares. The effects on asset prices and on money and credit volumes are very substantial, because the capital flows are large in relation to local markets. Local financial systems and capital markets are relatively small and undiversified. The range of assets is limited and the degree of bank intermediation low. The local financial system, used to administering few resources, is not equipped to allocate a burgeoning mass of credit efficiently. Likewise, the authorities are not well equipped to supervise a system that is growing rapidly both in volume and in the number of intermediaries. With a fixed or semi-fixed nominal exchange rate that initially enjoys strong credibility, investment in local assets yields high dollar returns. There are strong incentives to take positions in local assets financed by borrowing in international currency.

The real exchange rate is already high or tends to appreciate in the expansionary phase because inflation is higher than the sum of predetermined devaluation rates (zero in the case of a fixed exchange rate) plus international inflation. The pressure of rapidly expanding demand on non-tradable sectors contributes to currency appreciation.

Currency appreciation, trade liberalization and growth in domestic demand cause imports to rise rapidly and the trade deficit to widen. The current-account deficit also tends to grow, slowly at first but then more quickly as external debt mounts and the stock of foreign capital invested in the economy grows. Relative prices skew real investment towards non-tradable sectors. In the current-account balance, consequently, rising international currency returns for FDI are not matched by export growth.

Movements in the external accounts and reserves define one aspect of the cycle. The current-account deficit rises steadily, while capital flows can change abruptly. At some point the current-account deficit is larger than capital inflows. Reserves then peak and decline, resulting in a money and credit crunch. However, the cycle is not determined exclusively by this mechanical process: the scale of capital flows is not an exogenous factor. The portfolio decisions of local 
and external agents regarding the proportion of local assets they hold -the portion of the agent's portfolio that is exposed to country or currency risk-are affected by developments in the country's balance of payments and finances.

The domestic interest rate reflects the financial aspects of the cycle. It tends to fall in the first phase and rise in the second. Since exchange-rate policy initially enjoys great credibility, arbitrage between local and external financial assets and credits causes the rate to fall in the first phase. Low interest rates contribute to real and financial expansion. Under these circumstances, financial fragility ${ }^{8}$ increases markedly. In the second stage, the interest rate rises and episodes of illiquidity and insolvency begin to appear, first as isolated cases and then as a systemic crisis. What accounts for the rise in nominal and real interest rates?

Because the financial market is open in both directions, there is arbitrage between local and external assets, as already mentioned. The local-currency interest rate can be expressed as the sum of the international dollar rate which the country has to deal with plus the devaluation rate allowed for by the exchange-rate regime (zero in the case of a fixed exchange rate), plus a remainder answering to currency risk and local financial risk. The international rate that the country has to deal with, meanwhile, can be broken down into two terms: the interest rate paid by the United States Government (this is the base rate of the international financial market) plus a remainder to compensate for the risk of local dollar-denominated debt. Except in the case of some exceptional debt instruments, the floor for this is the premium paid by the dollar-denominated bonds of the country's government, known as the country risk premium.

The sum of the currency risk premium and the country risk premium -the aggregate price of devaluation risk and default risk- is the main factor determining local interest rates, so that when this variable rises interest rates tend upward as well. A steadily increasing current-account deficit (and, after a certain point, the tendency of reserves to shrink) undermines the credibility of the currency regime, while at the same time the likelihood of default on the debt issued increases. Increasing capital inflows are required to sustain the currency regime and enable external obligations to be serviced regularly. Consequently, risks tend to be priced upward. High risk premiums, and

\footnotetext{
${ }^{8}$ As defined by Minsky (1975).
}

thence high interest rates, are required to balance portfolios and attract capital from abroad. Economic activity contracts and episodes of illiquidity and insolvency serve to undermine further the credibility of the currency regime. This dynamic proved explosive in the cases studied. By the end of the process no interest rate is high enough to sustain demand for local financial assets. There are runs on Central Bank reserves, leading ultimately to the collapse of the currency regime. In the 1990s cases, the market was generally closed to new issues when the country risk premium reached a certain level.

The relative weight of the currency risk premium and the country risk premium was different in the $1990 \mathrm{~s}$ from what it had been in the 1970s. The shift was due to the different forms taken on by external financing in the two decades. In the 1970s, financing came mainly from international bank credits. The country risk premium was then the surcharge over the primary international rate charged by banks when lending to the country. The secondary debt market was insignificant. For Argentina and Chile in this context, the currency risk premium was the main factor driving interest rates higher in the second phase of the cycle, while the lending bank surcharge played a minor role. This can be explained by the behaviour of banks. Any bank that already has part of its portfolio invested in a country's assets has an interest in preserving the quality of that portfolio and the borrower's ability to pay. Consideration of the sunk portfolio influences decisions about the scale and pricing of new lending.

In the 1990s, on the other hand, most financing was raised by issuing bonds and other debt instruments in a primary market in which there were many different participants. The debt securities issued were traded daily in an active secondary market. The country risk premium was established by the continuous re-pricing of securities in this market. In that decade, rising country risk premiums, resulting from falling prices for the debt securities of the country concerned in the global secondary market, were the main driver of higher interest rates in the contractionary phase of the cycle. The debt market in this recent phase of globalization is more volatile than the credit market of the 1970s. It is more vulnerable to contagion and herd movements.

\section{Budget deficits and public debt}

The above analysis of developments in the economies identifies certain stylized facts that were present in all the processes leading to the crises considered. The 
description of the stylized facts focuses on the linkage between the finances and real economy of a country and the international financial system. There is positive feedback during the boom period and negative feedback during the contraction. It will be noted that in the description of national economies the private and public sectors are not analysed separately. Budget deficits financed with external capital are tacitly included among the local destinations for capital inflows and consolidated with the private-sector deficit. The external debt of the public sector is part of the country's total external debt and is not analysed separately.

This approach is easily explained: fiscal sustainability did not play a notable role in creating the crises in Chile (1982), Mexico (1994-1995), Argentina (1995) or Brazil (1998-1999), or in the Asian crises of 1997-1998. ${ }^{9}$

Now, a rapidly growing public debt which comes to be viewed as unsustainable by the market that has been financing it may of course be the root cause and trigger for a crisis. Certainly there was a substantial budget deficit and public debt in the Argentine crises of 1981-1982 and 2001-2002, and these crises have often been explained by reference to that circumstance.

The origin of the Argentine crisis of 1981-1982 is not to be found in the fiscal accounts, however. In this case, only half of the external debt was in the public sector prior to the crisis and the military regime did not seem to be having too much trouble adjusting the public finances. The fiscal deficit and its external financing were the result of government decisions which did not raise any special problems. Government policy was strongly endorsed by advisers who had signed up to the "monetary approach to the balance of payments" and maintained, at that time, that monetary policy and monetary policy alone was what determined the balance-of-payments outcome and the level of reserves. As long as discipline and control were exercised over domestic credit -it was argued- there would be no problem in financing the public-sector deficit.

\footnotetext{
${ }^{9}$ If the public sector has some deficit to finance and has issued some debt, the increase in interest rates during the contractionary phase tends to widen the deficit and cause debts to accumulate faster, in both the public and private sectors. As their crises neared, Mexico and Brazil had trouble administering the public debt. But this is not the point. What matters is the mechanism causing risks and interest rates to rise, i.e., whether the original source of uncertainty is to be found in the dynamic of the public accounts and financing needs or in the dynamic of the external accounts and financing needs. In Brazil and Mexico, the second phase of the cycle was not brought on by fiscal problems.
}

Furthermore, it was not the banks lending to the public sector that brought on the crisis by restricting the supply of financing or raising its price. The international banks carried on supplying financing to the public sector at a low premium until the last moments of the currency regime. Both in the case of Argentina and in the parallel one of Chile, the domestic financial crisis began to manifest itself at least a year before the collapse of the currency regime.

The 2001-2002 Argentine crisis was different. On that occasion the public debt was the main component of the country's external debt. Analysis of the case reveals the cyclical macroeconomic dynamic described earlier, but side by side with a fiscal deficit and a steadily growing public debt, largely financed from external resources. This did not happen in the first cycle (19911995) but in the second one, beginning in 1996, after the crisis triggered by the Tequila effect.

The budget deficit had its origin in the social security system. This was partly because of the reform implemented in late 1994, whereby much of the system's revenue was transferred to the private financial sector ${ }^{10}$ while public pension spending was maintained, and partly because the Government reduced employers' contributions in an effort to improve competitiveness, which had been weakened by currency appreciation. In any event, in the second half of the 1990s the main component forcing current public spending upward was the interest on the public debt. The higher interest rates characteristic of the contractionary phase of the cycle directly impacted the growth of the public debt, contributing to a perverse dynamic of higher indebtedness and higher risk (Damill and Frenkel, 2003).

An investor's sustainability analysis reveals many sources of uncertainty in this case. Firstly, there is the macroeconomic dynamic common to processes that lead to crisis: the current-account deficit and external debt increase, there is a growing need for capital inflows, and the external financial fragility of the economy as a whole also increases. In parallel with this, the public debt rises and public-sector financing needs grow.

The tendency for the country risk premium and interest rate to rise may be associated with the situation of the country's external accounts or with developments in the public finances. Or it may be associated with both, as it in fact was in the reports of investment fund analysts and risk rating agencies.

${ }^{10}$ To the Pension Fund Administrators (AFJP). 
Although doubts about the sustainability of the public debt may have weighed significantly in investors' risk assessments, however, this should not be allowed to mask the original sources of the public-sector deficit and debt. The main cause was not an extravagant fiscal policy but the combined effect of external fragility and contagion from the Asian, Russian and Brazilian crises. The second cycle of the convertibility regime and the recent Argentine crisis are not an exceptional case. In accounting for it, the Ockham's razor principle of parsimony of assumptions suggests that the focus should be on the stylized facts it has in common with the other crises considered.

IMF and some analysts (in particular Michael Mussa, former Chief Economist of IMF) ${ }^{11}$ are emphatic in attributing the crisis to the budget deficit and the dynamic of the public debt, without considering how these originated. The implicit suggestion is that the experiment would have been sustainable and the crisis would not have happened had fiscal policy been different.

Were it to acknowledge that the growth of the public debt was largely an endogenous consequence of the rise in the country risk premium, IMF would be placed in an uncomfortable position and would be obliged to look hard at its own actions. In the first half of the 1990s, the institution gave both intellectual and practical support to high fixed exchange-rate policies, including the convertibility system adopted by Argentina in 1991. Later, when the Mexican crisis made the shortcomings of such exchange-rate policies plain, IMF changed its diagnostic. The new approach recognized the volatility of capital flows, and floatingrate policies were now recommended. But a favourable judgement was passed on fixed exchange-rate policies with a high degree of institutional and legal rigidity, such as currency board systems or dollarization. This category came to be one of the "corner solutions" accepted by the new orthodoxy (Fischer, 2001). The umbrella of the new orthodoxy was broad enough to cover the Argentine convertibility regime.

IMF commitment to the convertibility regime culminated in the emergency financing granted to Argentina in late 2000. The conditions did not include any significant change in policy arrangements. This support was clearly intended to extend the life of the system, even though there were clear indications that it was unsustainable. Multilateral resources ended up financing debt service payments and capital flight. IMF agreed to a disbursement in August 2001, when the Argentine authorities were virtually alone in their apparent belief that the system was still sustainable.

It is understandable that IMF might not wish to dwell on that episode. Attributing Argentina's problems and crisis exclusively to fiscal variables is convenient, as it relieves IMF of all responsibility for the course of events and its disastrous consequences, including not just those suffered by the people of the country, but also the capital losses of foreign investors. What is less understandable is that IMF should subsequently have held out for so long against providing a minimal level of support -rolling over capital repayments due to it- for policies designed to cope with the consequences of a crisis that had been caused by policies previously supported by the institution. Paradoxically, IMF officials justified this reluctance by alluding darkly to "mistakes we made with Argentina in the past”.

\section{III}

\section{The diversity of regional experience and "crisis prevention measures"}

\section{Experiences in the region}

Section II gave a brief description of financial globalization in the region during the 1990s. A closer look at the routes followed by those countries in the region that became emerging markets reveals significant

${ }^{11}$ See Mussa (2002). differences in the nature of the capital market deregulation and liberalization measures taken, and in the volume and composition of capital flows. Although they were engaged in the same process, the countries followed different routes towards international financial integration.

These different routes are a defining aspect of each country's growth model. They are historical processes 
in which the country's engagement in the international economy alters as a result of changes in its international trade and the build-up of external debt and foreign direct investment. This is reflected in changes in the balanceof-payments structure. The route taken in each case is influenced by the conditions obtaining at any given time, and these depend on the policies, incentives and relative prices of the moment, but also on previous history. The variable that most obviously characterizes this property of countries' integration processes is the stock of external debt as it relates to certain flows, such as output and exports.

The routes that led to high debt levels and increased vulnerability involved full capital-account deregulation, currency appreciation and a passive role for monetary policy. These were the cases where economic policy was oriented towards full integration into the international financial system and where capital flows were an essential policy ingredient. A fixed nominal exchange rate and full capital-account deregulation entailed a passive monetary policy. Argentina throughout the decade, Brazil from 1994 and Mexico up to 1995 are instances where countries took these more vulnerable routes.

By contrast, there were sounder routes to integration. In these cases, economic policies focused on growth and price stability and attached importance to a competitive real exchange rate, so that they included the real exchange rate among their objectives. Examples are Chile and Colombia in the first half of the 1990s. These countries adopted crawling band exchange-rate regimes, regulated capital flows by setting rates that differentiated by the type of flow (which meant retaining some control over the currency market) and implemented sterilization policies. These policy packages did not fully meet all their objectives, but they did result in more robust performance than in the other cases referred to above.

A glance at the conditions obtaining in the region's countries before the boom in capital flows makes it easier to understand these differences in policy stance. In the cases of Mexico, Argentina and Brazil, the main policy objective was to bring an end to a long period of very high inflation and economic stagnation. The lower inflation and rising demand and business activity that characterize the first phase of capital inflows proved a blessing in those cases. By contrast, Chile and Colombia had been growing briskly since the mid-1980s and came to the capital flow boom with comparatively low inflation rates of some $30 \%$ a year. It is understandable that these countries should have sought to defend the stability of their relative prices and avoid the shocks caused by a large injection of outside funds (Damill, Fanelli and others, 1993; Frenkel, 1995).

Comparative analysis of these Latin American experiences, combined with the negative and positive lessons of other experiences, has made it possible to distil a set of national policy recommendations to forestall crises.

\section{2. "Crisis prevention measures"}

Firstly, there is consensus about the importance of prudential regulations. Conventional regulatory criteria, however, are largely procyclical. Consequently, prudential regulation should not take account solely of microeconomic risks, but should also consider macroeconomic and systemic risks, such as those deriving from currency misalignments and the buildup of short-term foreign-currency debts (Ocampo, 2003). In any case, offloading the entire responsibility for prudential regulation on to recipient countries imposes heavy costs upon them.

The crises experienced leave no room for doubt about the incompatibility of fixed exchange rates with volatile capital flows. This lesson has been taken on board by IMF, as mentioned above. In relation to the exchange-rate regime, however, while there is consensus about the need for flexibility, there is an unfinished debate about the scope and benefits of intervention in the currency market. IMF supports a pure float and shifts the entire burden of price and exchangerate stability on to the anchor of monetary policy. Despite this, most countries actually adopt intermediate regimes of managed flexibility which include different types of currency market intervention by the monetary authorities.

Comparative analysis of the routes taken towards integration has suggested other "crisis prevention measures" focusing on the regulation of capital inflows during boom periods. These regulations are based on the experience of Chile and Colombia in the first half of the 1990s and on the regulations maintained by some Asian economies, such as Taiwan (Agosin, 2001).

A flexible exchange rate is enough in itself to discourage certain types of short-term capital flows, but a free float in situations of capital flow volatility can result in the nominal and real exchange rate becoming unacceptably volatile. Applying direct controls (or reserve requirements for incoming capital, as in Chile and Colombia) can help stabilize the currency market and capital inflows and alter the time profile of the capital 
that comes in, discouraging short-term flows. Over and above its short-term stabilization role, the objective of regulatory policy is to smooth out capital inflows so that they behave as far as possible in a stable, predictable way. ECLAC has led the way in promoting this policy stance and outlook (ECLAC, 2002).

IMF came out against capital flow regulation, even in the case of prudential regulations during boom periods. The institution in fact went completely the other way, seeking to make full deregulation of the capital account compulsory for member countries. Here, as with the exchange-rate issue, the IMF took extreme positions that owed more to belief in the selfstabilizing virtues of markets than to a careful weighing of experience.

"Crisis prevention measures" embody the lessons that can be drawn from the region's experience, but their recommendations are applicable at times when there is an upsurge in capital flows. There are other items on the regional and global agenda.

\section{IV}

\section{Segmented integration and financing traps}

\section{External financing traps ${ }^{12}$}

Those countries in the region that followed routes leading to greater vulnerability tended to be caught in financial traps. Argentina in 1998-2001 is a clear example of this. Countries can find themselves in financing traps even if they have already experienced and overcome a crisis. In 1999, for example, Brazil corrected the main features of its previous macroeconomic policy arrangements. But this change could not undo the structural legacy of the course it had taken beforehand. Financial traps derive from two main links between the economy and the international financial market. The first link arises because of the great volume of financing needs. The need to roll over debt and finance large structural current-account deficits becomes the main element in the country's relationship with the international financial market. This makes the country highly vulnerable to the effects of contagion or any other source of volatility. It also makes selffulfilling prophecies more likely. The market assesses this situation and reacts by imposing high country risk rates. The country loses freedom of manoeuvre in economic policy.

The second link results from the effects on interest rates and financial asset prices. The high country risk premium makes external financing more expensive, contributing to a further deterioration of debt indices. Meanwhile, the sum of the international rate plus the country risk premium sets the floor for the local real

${ }^{12}$ See Frenkel (2003). interest rate. Integration of the emerging market with the international financial market results in segmented integration where the local interest rate is significantly higher than the international one. The negative effects of high interest rates on growth and on domestic and external financial fragility were examined in some detail above, and this point was highlighted as an element in the dynamic leading to crises. What we would stress here is the phenomenon of segmented integration, quite apart from the crises to which it may give rise.

\section{Segmented integration}

Persistently high country risk premiums are an unforeseen consequence of financial globalization. From the outset, advocates of globalization presented full integration between local financial systems and the international system as the ideal state towards which the process should ultimately converge. Full integration entails a global system of intermediation in which the yield of the public's assets, on the one hand, and the cost of capital for borrowers, on the other, are the same for economically equivalent transactions, irrespective of the geographical location of savers and investors.

Full integration -it was argued- ought to lower intermediation costs and the cost of capital in developing countries. Insofar as the relative situation of developing countries offered greater business opportunities, this should result in investment and financing flows that would tend to close the development gap.

Convergence towards full integration as a result of the globalization process would have meant a steady 
reduction in country risk premiums. This has not happened. On the contrary, the experience accumulated since the Asian crisis suggests that globalization has created a segmented system of integration in which the cost of capital is, in many cases, systematically higher in emerging market economies than in developed countries.

To sterilize the effects of sovereign risk, it might be thought that it would be sufficient to attain fiscal balance and have no need of new public securities issues. It could be argued -and many have done sothat the problem lies exclusively with the finances of the public sector. This is not the case. A country's finances may be in balance or surplus, but this does not guarantee that its economy will have the necessary foreign currency resources available to meet debt service and repayment obligations in dollars. Furthermore, it may happen that the government has the foreign currency resources it needs to meet its own requirements, but the wider economy does not, so that the currency required to service the external privatesector debt is unavailable (Frenkel, 2003). Under these conditions, the authorities may be forced (or choose) to suspend local currency convertibility -or to suspend payments abroad, in the case of a dollarized economyand to force default on contracts. Sovereignty makes this possible. Sovereign risk means more than the risk of fiscal insolvency.

It seems hard to find a way out of financing traps or, more broadly, to create an international context that can prevent segmented integration unless a major effort of international cooperation is made. Globalization has created a system that lacks many of the institutions built up over time in individual countries to improve the workings and safeguard the stability of national systems (Eatwell and Taylor, 2000; Stiglitz, 2002).

Until fairly recently it seemed as though some progress had been made. The scale and consequences of the Asian and Russian crises led the central countries to go some way towards creating international institutions responsible for supervision, crisis prevention and organized crisis management. Some currency was given to the idea that borrowers and lenders had a joint responsibility and that adjustment costs should be shared. After a period in which initiatives were scaled back, however, as a degree of complacency set in during 1999 and 2000, thinking hostile to public intervention is once again in the ascendancy. The massive IMF-led bail-out packages were the only international policy initiative in this area. They did indeed help prevent default in most cases. The existence of this instrument did not stop crises happening, however. Nor, particularly after the Russian crisis, did it bring down persistently high country risk levels or prevent financial traps from arising.

Things got worse. The role of bail-out packages was significantly reduced, while the IMF, with its Krueger initiative, envisaged international reform aimed solely at facilitating negotiations subsequent to default. But even this limited initiative has not prospered. The prospects for countries with high risk premiums are not encouraging.

\section{Bibliography}

Agosin, M. (2001): Korea and Taiwan in the financial crisis, in R. Ffrench-Davis (ed.), Financial crises in "successful" emerging economies, Washington, D.C., Brookings Institution Press/ECLAC.

Arellano, J.P. (1983): De la liberalización a la intervención. El mercado de capitales en Chile, 1974-83, Colección Estudios CIEPLAN, No. 11, Santiago, Chile.

Calvo, G., L. Leiderman and C. Reinhart (1996): Inflows of capital to developing countries in the 1990s, The Journal of Economic Perspectives, vol. 10, No. 2, Nashville, American Economic Association.

D'Arista, J. (2002): Financial regulation in a liberalized global environment, in J. Eatwell and L. Taylor (eds.), International Capital Markets. Systems in Transition, Oxford, Oxford University Press.

Damill, M., J. Fanelli and others (1993): Crecimiento económico en América Latina: experiencia reciente y perspectivas, Desarrollo económico, vol. 33, No. 130, Buenos Aires, Instituto de Desarrollo Económico y Social (IDES), JulySeptember.
Damill, M. and R. Frenkel (1987): De la apertura a la crisis financiera. Un análisis de la experiencia argentina de 1977 a 1982, Ensayos económicos, No. 37, Buenos Aires, Banco Central de la República Argentina (BCRA).

(2003): Argentina: Macroeconomic Performance and Crisis, document prepared for the IPD Macroeconomics Task Force Meeting (Barcelona, Spain, 2-3 June).

Díaz Alejandro, C. (1985): Good-bye financial repression, hello financial crash", Journal of Development Economics, vol. 19, No. 1, North-Holland, Elsevier.

Eatwell, J. (1997): International Financial Liberalization: The Impact on World Development, Office of Development Studies Discussion Papers Series, No. 12, New York, United Nations Development Programme (UNDP).

Eatwell, J. and L. Taylor (2000): Global Finance at Risk: The Case for International Regulation, New York, The New Press.

ECLAC (Economic Commission for Latin America and the Caribbean) (2002): Growth with Stability. Financing for Development in the New International Context, LC/G.2171-P, Santiago, Chile. United Nations publication, Sales No. E.02.II.G.20. 
Edwards, S. (1986): The order of economic liberalization of the current and capital account of the balance of payments, in M.A. Choksi and D. Papageorgiou (eds.), Economic Liberalization in Developing Countries, Oxford, Basil Blackwell.

Fanelli, J.M. and R. Frenkel (1993): On gradualism, shock treatment and sequencing, International Monetary and Financial Issues for the 1990s. Research Papers for The Group of Twenty-four, vol. 2, UNCTAD/GID/G.24/2, New York, United Nations.

Fischer, S. (2001): Exchange Rate Regimes: Is the Bipolar View Correct?, address delivered at the American Economic Association Meetings (New Orleans, 6 January 2001).

Ffrench-Davis, R. (ed.) (2001): Financial crises in "successful" emerging economies, Washington, D.C., Brookings Institution Press/ECLAC.

Ffrench-Davis, R. and J.P. Arellano (1983): Apertura financiera externa: la experiencia chilena entre 1973-1980, in R. FrenchDavis (ed.), Las relaciones financieras externas. Su efecto en las economías latinoamericanas, Mexico City, Fondo de Cultura Económica.

Frenkel, R. (1980): El desarrollo reciente del mercado de capitales en la Argentina, Desarrollo económico, vol. 20, No. 78, Buenos Aires, Instituto de Desarrollo Económico y Social (IDES), July-September.

(1983a): Mercado financiero, expectativas cambiarias y movimientos de capital, El trimestre económico, vol. 50 (4), No. 200, Mexico City, Fondo de Cultura Económica, OctoberDecember.

(1983b): Apertura financiera externa: el caso argentino, in R. Ffrench-Davis (ed.), Relaciones financieras externas y su impacto en las economías latinoamericanas, Mexico City, Fondo de Cultura Económica.

(1995): Macroeconomic Sustainability and Development Prospects: Latin American Performance in the 1990s, UNCTAD Discussion Paper, No. 100, unCTAD/osG/DP/100, Geneva, August. (2002): Capital market liberalization and economic performance in Latin America, in J. Eatwell and L. Taylor (eds.), International Capital Markets. Systems in Transition, Oxford, Oxford University Press.

(2003): From the Boom in Capital Inflows to Financial Traps, document prepared for the IPD Capital Market Liberalization Task Force Meeting_(Barcelona, Spain, 2-3 June).

IMF (International Monetary Fund) (1997): International Capital Markets. Development, Prospects, and Key Policy Issues, World Economic and Financial Surveys, Washington, D.C., September.

Krueger, A. (1986): Problems of liberalization, in M.A. Choksi and D. Papageorgiou (eds.), Economic Liberalization in Developing Countries, Oxford, Basil Blackwell.

Minsky, H.P. (1975): John Maynard Keynes, New York, Columbia University Press.

Mussa, M. (2002): Argentina and the Fund: From Triumph to Tragedy, Washington, D.C., Institute for International Economics (IIE).

Ocampo, J.A. (2003): Capital-account and Counter-cyclical Prudential Regulations in Developing Countries, Informes y estudios especiales series, No. 6, LC/L.1820-P, Santiago, Chile, ECLAC. United Nations publication, Sales No. E.03.II.G.23.

Robichek, W. (1981): Some reflections about external public debt management, Estudios monetarios VII, Santiago, Chile, Banco Central de Chile.

Stiglitz, J. (2002): Globalization and Its Discontents, New York, W.W. Norton.

Taylor, L. (1991): Income Distribution, Inflation, and Growth. Lectures on Structuralist Macroeconomic Theory, Cambridge, Massachusetts, The MIT Press.

(1998): Lax Public Sector and Destabilizing Private Sector: Origins of Capital Market Crises, CEPA Working Papers, No. 11, New York, Center for Economic Policy Analysis (CEPA).

Williamson, J. (1983): Open Economy and the World Economy: A Textbook in International Economics, New York, Basic Books. 